\title{
Hypoxia-Triggered In Situ Self-Assembly of a Charge Switchable Azo Polymer with AIEgens for Tumor Imaging
}

Jiajia Shen, Kuanchun Shao, Wenlong Zhang and Yaning He*

Department of Chemical Engineering

Key Laboratory of Advanced Materials (MOE), Tsinghua University

Beijing 100084 China.

E-mail: heyaning@mail.tsinghua.edu.cn 


\section{Table of Contents}

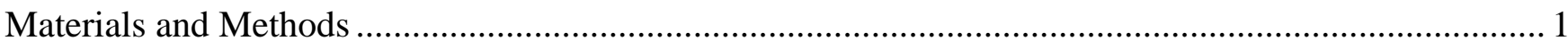

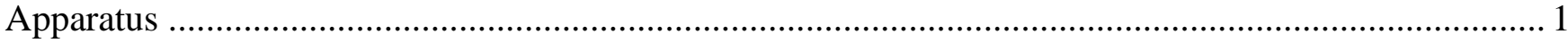

Synthesis of 4-(4'-(diphenylamino)-[1,1'-biphenyl]-4-yl)-1-(2-(acryloyloxy)ethyl)pyridin-1-ium

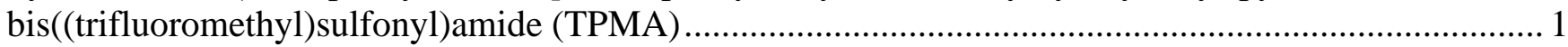

Synthesis of 4-((4(hydroxymethyl)phenyl)diazenyl)phenol (AZO) .................................................... 2

Synthesis of 4-((4-(2-(2-(2-methoxyethoxy)ethoxy)ethoxy)phenyl)diazenyl)phenyl)methanol (EAZO). 2 Synthesis of 1-(4-(bromomethyl)phenyl)-2-(4-(2-(2-(2-methoxyethoxy)ethoxy)ethoxy) phenyl)

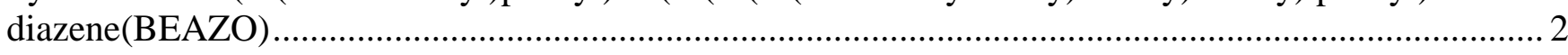

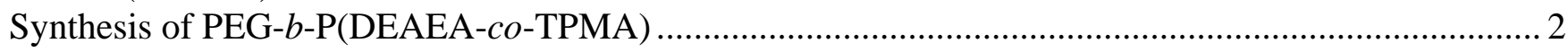

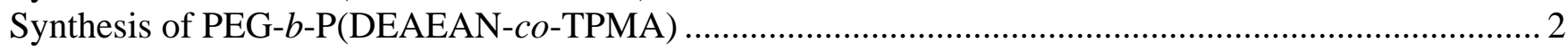

Enzymatic reduction reaction of PEG- $b$-P(DEAEAN-co-TPMA) ................................................... 3

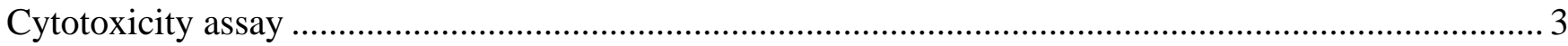

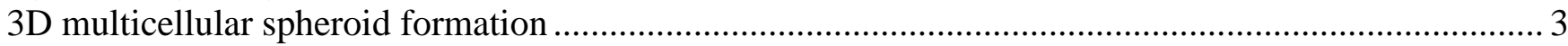

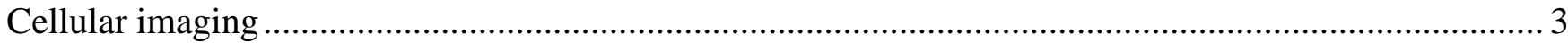

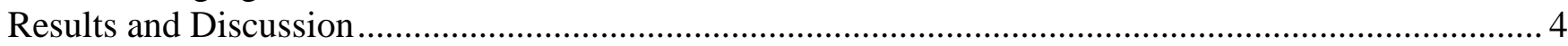

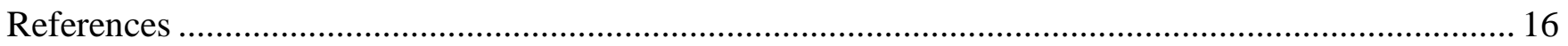




\section{Materials and Methods}

Azobis(isobutyronitrile) (AIBN), tetrabromomethane $\left(\mathrm{CBr}_{4}\right)$, triphenylphosphine $\left(\mathrm{PPh}_{3}\right)$, potassium iodide (KI), 4-Aminobenzyl alcohol, triethylamine (TEA) and tetrahydrofuran (THF) with molecular sieve were purchased from J\&K Scientific Co., Ltd. Methoxy poly(ethylene oxide)-2-(dodecylthiocarbonothioylthio)-2-methylpropionate (PEG-DDMAT, average $\mathrm{M}_{\mathrm{n}} \approx 6000$ ) and 2-(diethylamino)ethyl acrylate (DEAEA) were acquired from Sigma-Aldrich. 4-(diphenylamino) phenylboronic acid, 4-(4-bromophenyl) pyridine, potassium carbonate $\left(\mathrm{K}_{2} \mathrm{CO}_{3}\right)$ and tetrakis(triphenylphosphine)palladium $\left(\mathrm{Pd}\left(\mathrm{PPh}_{3}\right)_{4}\right)$ were bought from Energy Chemical Co., Ltd. 1-bromo-2-(2(2-methoxyethoxy)ethoxy)ethane was purchased from Bide Pharmatech Ltd. Acrylylchloride, 2-iodoethanol, bistrifluoromethanesulfonimide lithium salt, and phenol were acquired from TCl. Rat liver microsomes was purchased from $\mathrm{CHI}$ Scientific, Inc. (Jiangsu, China) Phosphate buffer saline ( $\mathrm{pH}$ 7.2-7.4) was acquired from Beijing Solarbio Co., Ltd. Human cervical cancer cells line HeLa was obtained from China Infrastructure of Cell Line Resource. Dulbecco's Modified Eagle Medium (DMEM) (Gibco), fetal bovine serum (FBS) and penicillin/streptomycin were purchased from Thermo Fisher Scientific. WST-1 assay was provided by Takara Bio Inc. Other reagents used in this work were provided by Tongguang Fine Chemical Co., Ltd. (Beijing, China) AIBN was recrystallized in anhydrous ethanol before use. Other reagents purchased were used directly without additional processor. Ultrapure water (resistivity $>18 \mathrm{MD} \cdot \mathrm{cm}$ ) was purified by Milli-Q water purification system. Unless otherwise noted, all reagents and solvents were analytical grade.

\section{Apparatus}

All ${ }^{1} \mathrm{H}$ NMR were recorded on a JEOL JNM-ECA 600 NMR spectrometer. The molecular weights and molecular weights dispersity index (PDI) of the polymer were measured by gel permeation chromatography (GPC) equipped with a Waters $515 \mathrm{HPLC}$ pump, Wyatt DAWN HELEOS II, Wyatt ViscoStar II, Wyatt Optilab rEX system using N,N-dimethylformamide as eluent at $60^{\circ} \mathrm{C}$. The UV-vis spectra were characterised with an Agilent Cary 300 UV-vis spectrophotometer. The fluorescence spectra were measured by a HITACHI F7000 fluorescence spectrophotometer. Dynamic light scattering (DLS) was determined by ALV/DLS/SLS-5022F Laser Light Scattering System with a solid-state $17 \mathrm{~mW}$ He-Ne laser $(\lambda=633 \mathrm{~nm})$ at a fixed angle of $90^{\circ}$. TEM observation was carried out with a HITACHI $\mathrm{H}-7650 \mathrm{~B}$ TEM at $80 \mathrm{kV}$. ESI-MS was measured on LCMS-IT/TOF (Shimadzu.Japan). Fluorescence imaging of HeLa cells and multicellular tumor spheroid were performed by a Nikon Ti2-E confocal laser scanning microscope.

\section{Synthesis of 4-(4'-(diphenylamino)-[1,1'-biphenyl]-4-yl)-1-(2-(acryloyloxy)ethyl)pyridin-1-ium bis((trifluoromethyl)sulfonyl)amide (TPMA)}

TPMA was synthesized according to a previously reported method..$^{1-4} \mathrm{~A} 100 \mathrm{~mL}$ round-bottom flask charged with TP $(0.73 \mathrm{~g}, 1$ $\mathrm{mmol})$, TEA $(0.20 \mathrm{~g}, 2 \mathrm{mmol})$, and THF $(40 \mathrm{~mL})$ was kept in an ice-water bath under argon atmosphere. After stirred the mixture for 30 minutes, acryloyl chloride $(0.14 \mathrm{~g}, 1.5 \mathrm{mmol})$ in $10 \mathrm{~mL}$ THF was added dropwise. After $12 \mathrm{~h}$ of reaction, solvent was removed under reduced pressure. The residues were redissolved in dichloromethane and washed with water and saturated brine. Then the organic layer was dried over anhydrous $\mathrm{MgSO}_{4}$, filtered, and concentrated on a rotary evaporator. The crude product was purified by column chromatography using dichloromethane/methanol=10/1 as eluent to afford TPMA as orange solid powders (yield: $85 \%)$. ${ }^{1} \mathrm{H}$ NMR $(600$ $\mathrm{MHz}$, Chloroform-d) $\delta 8.76(\mathrm{~d}, \mathrm{~J}=7.0 \mathrm{~Hz}, 2 \mathrm{H}), 8.21(\mathrm{~d}, \mathrm{~J}=6.9 \mathrm{~Hz}, 2 \mathrm{H}), 7.88(\mathrm{~d}, \mathrm{~J}=8.6 \mathrm{~Hz}, 2 \mathrm{H}), 7.79(\mathrm{~d}, \mathrm{~J}=8.5 \mathrm{~Hz}, 2 \mathrm{H}), 7.52(\mathrm{~d}, \mathrm{~J}=$ $8.7 \mathrm{~Hz}, 2 \mathrm{H}), 7.32-7.27(\mathrm{~m}, 4 \mathrm{H}), 7.18-7.11(\mathrm{~m}, 6 \mathrm{H}), 7.08(\mathrm{~d}, \mathrm{~J}=7.5 \mathrm{~Hz}, 2 \mathrm{H}), 6.43(\mathrm{~d}, \mathrm{~J}=0.9 \mathrm{~Hz}, 1 \mathrm{H}), 6.09(\mathrm{dd}, \mathrm{J}=17.3,10.5 \mathrm{~Hz}$, $1 \mathrm{H}), 5.91(\mathrm{~d}, \mathrm{~J}=11.3 \mathrm{~Hz}, 1 \mathrm{H}), 4.97-4.88(\mathrm{~m}, 2 \mathrm{H}), 4.71-4.63(\mathrm{~m}, 2 \mathrm{H})$.

Scheme S1. Synthesis route of TPMA

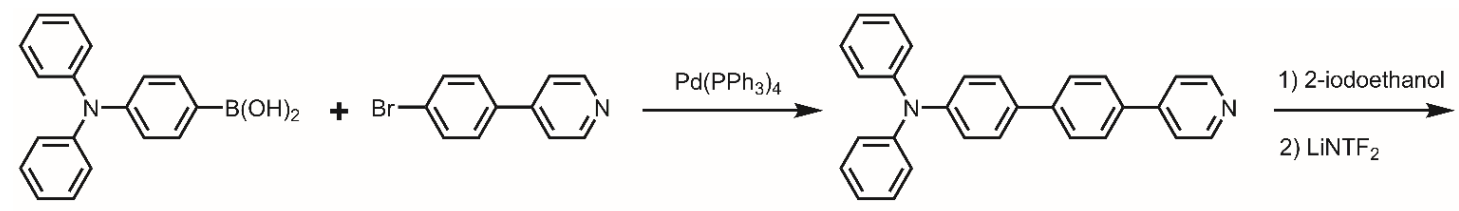

TBP

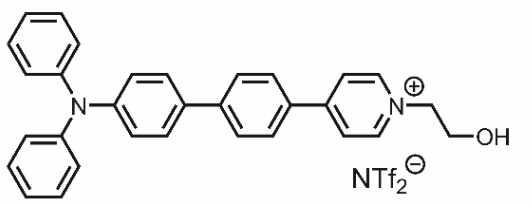

TP
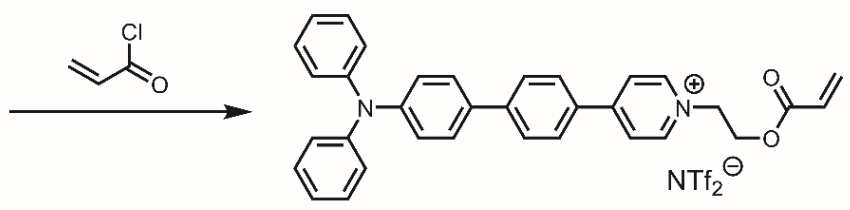

TPMA 


\section{Synthesis of 4-((4(hydroxymethyl)phenyl)diazenyl)phenol (AZO)}

A $100 \mathrm{~mL}$ round-bottom flask charged with 4-aminobenzyl alcohol $(4.06 \mathrm{~g}, 33 \mathrm{mmol}), \mathrm{HCl}(36 \%, 9.60 \mathrm{~mL})$ and $30 \mathrm{~mL}$ deionized water was kept at an ice-water bath for 30 minutes. Then sodium nitrite $(2.39 \mathrm{~g}, 34.7 \mathrm{mmol})$ in $20 \mathrm{~mL}$ of water was added dropwise to afford diazonium salt of (4-aminophenyl)methanol. After $1 \mathrm{~h}$ of reaction, the mixture was added dropwise to another $250 \mathrm{~mL}$ roundbottom flask charged with phenol $(3.10 \mathrm{~g}, 33 \mathrm{mmol}), \mathrm{NaOH}(3 \mathrm{~g}, 75 \mathrm{mmol})$ and $60 \mathrm{~mL}$ deionized water. The mixture was stirred at $0^{\circ} \mathrm{C}$ for $12 \mathrm{~h}$, and dark brown solid gradually precipitated out from the solution during the reaction process. After filtration, the crude product was further purified by recrystallization in methanol to give AZO (yield: 85\%). ${ }^{1} \mathrm{H}$ NMR (600 MHz, DMSO-d6) $\delta 10.25$ (s, $1 \mathrm{H}$ ), 7.75 (dd, $\mathrm{J}=8.6,3.0 \mathrm{~Hz}, 4 \mathrm{H}), 7.45(\mathrm{~d}, \mathrm{~J}=8.4 \mathrm{~Hz}, 2 \mathrm{H}), 6.90(\mathrm{~d}, \mathrm{~J}=8.8 \mathrm{~Hz}, 2 \mathrm{H}), 5.31(\mathrm{t}, \mathrm{J}=5.7 \mathrm{~Hz}, 1 \mathrm{H}), 4.55(\mathrm{~d}, \mathrm{~J}=5.6 \mathrm{~Hz}, 2 \mathrm{H})$.

\section{Synthesis of 4-((4-(2-(2-(2-methoxyethoxy)ethoxy)ethoxy)phenyl)diazenyl)phenyl)methanol (EAZO)}

A $250 \mathrm{~mL}$ round-bottom flask charged with 1-bromo-2-(2-(2-methoxyethoxy)ethoxy)ethane ( $3.00 \mathrm{~g}, 13.2 \mathrm{mmol})$, AZO (2.70 g, 11.8 $\mathrm{mmol}), \mathrm{K}_{2} \mathrm{CO}_{3}(3.00 \mathrm{~g}, 21.7 \mathrm{mmol}), \mathrm{KI}(0.23 \mathrm{~g}, 1.40 \mathrm{mmol})$ and acetone $(100 \mathrm{~mL})$ was refluxed at $60^{\circ} \mathrm{C}$ for $48 \mathrm{~h}$ under argon atmosphere. After removing all solvent under reduced pressure, the residues were redissolved in dichloromethane and washed with brine for three times. Then the organic layer was dried over anhydrous $\mathrm{MgSO}_{4}$, filtered, and concentrated on a rotary evaporator. The crude product was purified by column chromatography using dichloromethane/methanol=25/1 as eluent to afford EAZO as orange solid powders (yield: 60\%). ${ }^{1} \mathrm{H}$ NMR $\left(600 \mathrm{MHz}\right.$, DMSO- $\left.\mathrm{d}_{6}\right) \delta 7.92-7.73(\mathrm{~m}, 4 \mathrm{H}), 7.48(\mathrm{~d}, \mathrm{~J}=12.2 \mathrm{~Hz}, 2 \mathrm{H}), 7.11(\mathrm{~d}, \mathrm{~J}=12.1 \mathrm{~Hz}, 2 \mathrm{H}), 5.31(\mathrm{~s}, 1 \mathrm{H})$ $4.56(\mathrm{~s}, 2 \mathrm{H}), 4.18(\mathrm{~s}, 2 \mathrm{H}), 3.75(\mathrm{~s}, 2 \mathrm{H}), 3.57(\mathrm{~s}, 2 \mathrm{H}), 3.40(\mathrm{~s}, 2 \mathrm{H}), 3.20(\mathrm{~s}, 3 \mathrm{H})$.

\section{Synthesis of 1-(4-(bromomethyl)phenyl)-2-(4-(2-(2-(2-methoxyethoxy)ethoxy)ethoxy) phenyl) diazene(BEAZO)}

A $100 \mathrm{~mL}$ round-bottom flask charged with EAZO (0.53 g, $1.41 \mathrm{mmol}), \mathrm{CBr}_{4}(0.70 \mathrm{~g}, 2.12 \mathrm{mmol})$ and dry THF (80 mL) was kept at an ice-water bath. $\mathrm{PPh}_{3}(0.56 \mathrm{~g}, 2.12 \mathrm{mmol})$ in THF $(5 \mathrm{~mL})$ was added dropwise in 10 minutes. The mixture was stirred at room temperature for $24 \mathrm{~h}$ under argon atmosphere. Solvent was concentrated on a rotary evaporator, and the crude product was purified by column chromatography using dichloromethane/methanol=50/1 as eluent to afford BEAZO as orange solid powders (yield: $60 \%$ ). ${ }^{1} \mathrm{H}$ NMR $(600 \mathrm{MHz}$, Chloroform-d) $\delta 7.96-7.80(\mathrm{~m}, 4 \mathrm{H}), 7.50(\mathrm{~d}, \mathrm{~J}=8.0 \mathrm{~Hz}, 2 \mathrm{H}), 7.02(\mathrm{~d}, \mathrm{~J}=8.6 \mathrm{~Hz}, 2 \mathrm{H}), 4.71-4.49(\mathrm{~m}, 2 \mathrm{H}), 4.26-$ $4.16(\mathrm{~m}, 2 \mathrm{H}), 3.93-3.86(\mathrm{~m}, 2 \mathrm{H}), 3.78-3.72(\mathrm{~m}, 2 \mathrm{H}), 3.67(\mathrm{dt}, \mathrm{J}=20.5,4.7 \mathrm{~Hz}, 4 \mathrm{H}), 3.55(\mathrm{t}, \mathrm{J}=7.1 \mathrm{~Hz}, 2 \mathrm{H}), 3.37(\mathrm{~s}, 3 \mathrm{H})$.

Scheme S2. Synthesis route of BEAZO
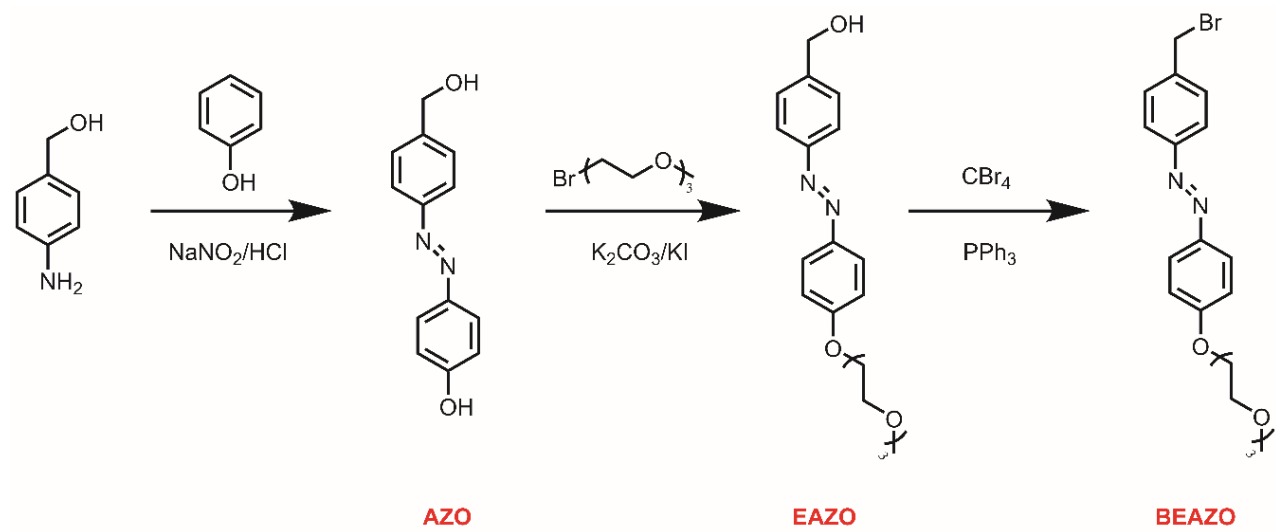

\section{Synthesis of PEG-b-P(DEAEA-co-TPMA)}

PEG- $b$-P(DEAEA-co-TPMA) was prepared via reversible addition-fragmentation chain transfer (RAFT) polymerization using $\mathrm{PEG}_{6000}$-DDMAT as an macroRAFT agent. A $10 \mathrm{~mL}$ Schlenk flask charged with DEAEA (0.085 g, $\left.0.5 \mathrm{mmol}\right)$, TPMA (0.39 g, $\left.0.5 \mathrm{mmol}\right)$, PEG-DDMAT $(0.30 \mathrm{~g}, 0.05 \mathrm{mmol})$, AIBN $(0.82 \mathrm{mg}, 0.005 \mathrm{mmol})$ and dry THF $(4 \mathrm{~mL})$ was carefully degassed via three freeze-pumpthaw cycles. Then the mixture was stirred at $65^{\circ} \mathrm{C}$ for $24 \mathrm{~h}$ under argon atmosphere. After the reaction was completed, the flask was put into liquid nitrogen to terminate the reaction. The polymer solution was diluted with THF and then precipitated into an excess of cold diethyl ether three times to afford PEG- $b-\mathrm{P}($ DEAEA-co-TPMA) as orange solid powders (yield: $70 \%$ ). 
A $10 \mathrm{~mL}$ round-bottom flask was charged with PEG- $b$-P(DEAEAN-co-TPMA) $(0.30 \mathrm{~g}$, containing $0.19 \mathrm{mmol}$ DEAEA), BEAZO (0.33 $\mathrm{g}, 0.75 \mathrm{mmol}$ ), and $10 \mathrm{~mL}$ THF. Then the mixture was stirred at $50^{\circ} \mathrm{C}$ for 3 days under argon atmosphere. After the reaction was completed, the polymer mixture was diluted with THF and then precipitated into an excess of cold diethyl ether three times to afford PEG- $b$-P(DEAEAN-co-TPMA) as orange solid powders (yield: $90 \%$ ).

\section{Enzymatic reduction reaction of PEG-b-P(DEAEAN-co-TPMA)}

$3 \mathrm{~mL}$ PEG- $b$-P(DEAEAN-co-TPMA) $\left(0.05 \mathrm{mg} / \mathrm{mL}\right.$ in PBS buffer) was bubbled with $\mathrm{N}_{2}$ for $1 \mathrm{~h}$ to remove dissolved oxygen. And then $50 \mu \mathrm{L}$ rat liver microsomes and $50 \mu \mathrm{L} \mathrm{NADH}(75.4 \mathrm{mM}, 0.5 \mathrm{mg})$ dissolved in PBS (PH=7.4) as a coenzyme were added and the reaction was kept at $37^{\circ} \mathrm{C}$ for $24 \mathrm{~h}$ under $\mathrm{N}_{2}$ atmosphere.

\section{Cytotoxicity assay}

HeLa cells were seeded in 96-well plates at a density of $5 \times 10^{3}$ cells per well, and incubated for $24 \mathrm{~h}$ under normoxic $\left(21 \% \mathrm{v} / \mathrm{v} \mathrm{O}_{2}\right)$ or hypoxic $\left(1 \% \mathrm{v} / \mathrm{v}_{2}\right)$ condition. Then PEG- $b$-P(DEAEAN-co-TPMA) was added at the final concentration of $0.2,0.1,0.05,0.02,0.01$ and $0.001 \mathrm{mg} / \mathrm{mL}$ for another $24 \mathrm{~h}$. After that, $20 \mu \mathrm{L}$ premix WST-1 solution was added to each well and incubated for another $1 \mathrm{~h}$. Absorbance was measured using an Infinite M200 PRO microtiter plate reader at $440 \mathrm{~nm}$. All experiments were carried out with four replicates, and the data were averaged.

\section{D multicellular spheroid formation}

3D multicellular spheroids were prepared in agarose-coated 96-well plates according to a previously reported method. ${ }^{5}$ Two hundred microliters of a $2.5 \times 10^{4}$ cells $/ \mathrm{mL}$ single cell suspension was plated onto agarose-coated (sterile, $1.5 \%$ (w/v) in DMEM) 96 -well microplates, and centrifuged for $15 \mathrm{~min}$ at $1500 \mathrm{rcf}$. Then the cells were allowed to aggregate for $96 \mathrm{~h}$ without motion, leading to the formation of single spheroids.

\section{Cellular imaging}

HeLa cells were seeded on $35 \mathrm{~mm}$ glass-bottomed dishes and cultured overnight before the assay. Then cells were incubated under normoxic $\left(21 \% \mathrm{v} / \mathrm{v} \mathrm{O}_{2}\right)$ or hypoxic $\left(10 \%, 5 \%, 3 \%, 1 \% \mathrm{v} / \mathrm{v} \mathrm{O}_{2}\right)$ condition for $24 \mathrm{~h}$ as preculture, and then treated with test polymer (final concentration $0.02 \mathrm{mg} / \mathrm{mL}$ ) for another $6 \mathrm{~h}$ under the same condition. Fluorescence images were captured using a Nikon Ti2-E confocal laser scanning microscope.

3D multicellular spheroids were harvested after approximately 4 days of growth. Test polymers were then added to the wells with final concentration of $0.02 \mathrm{mg} / \mathrm{mL}$ and incubated for $24 \mathrm{~h}, 48 \mathrm{~h}, 72 \mathrm{~h}$ and $96 \mathrm{~h}$. Fluorescence images were captured by Nikon Ti2-E confocal laser scanning microscope. The excitation wavelength of the laser was $405 \mathrm{~nm}$, and the emission spectra were integrated over the range of $550-590 \mathrm{~nm}$. 


\section{Results and Discussion}

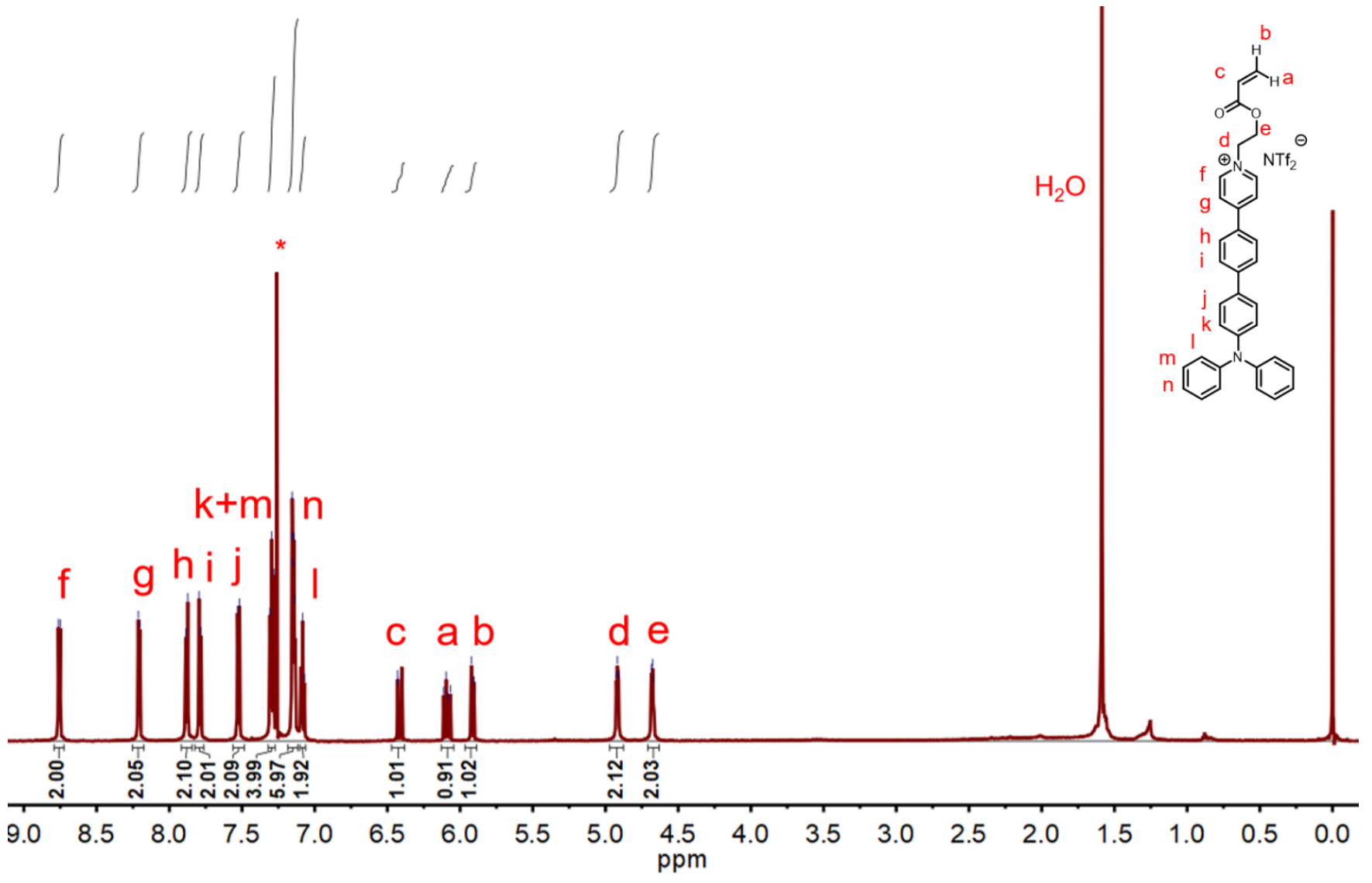

Figure S1(a). ${ }^{1} \mathrm{H}$ NMR spectra of TPMA in $\mathrm{CDCl}_{3}$. The solvent peaks are marked with asterisks. 

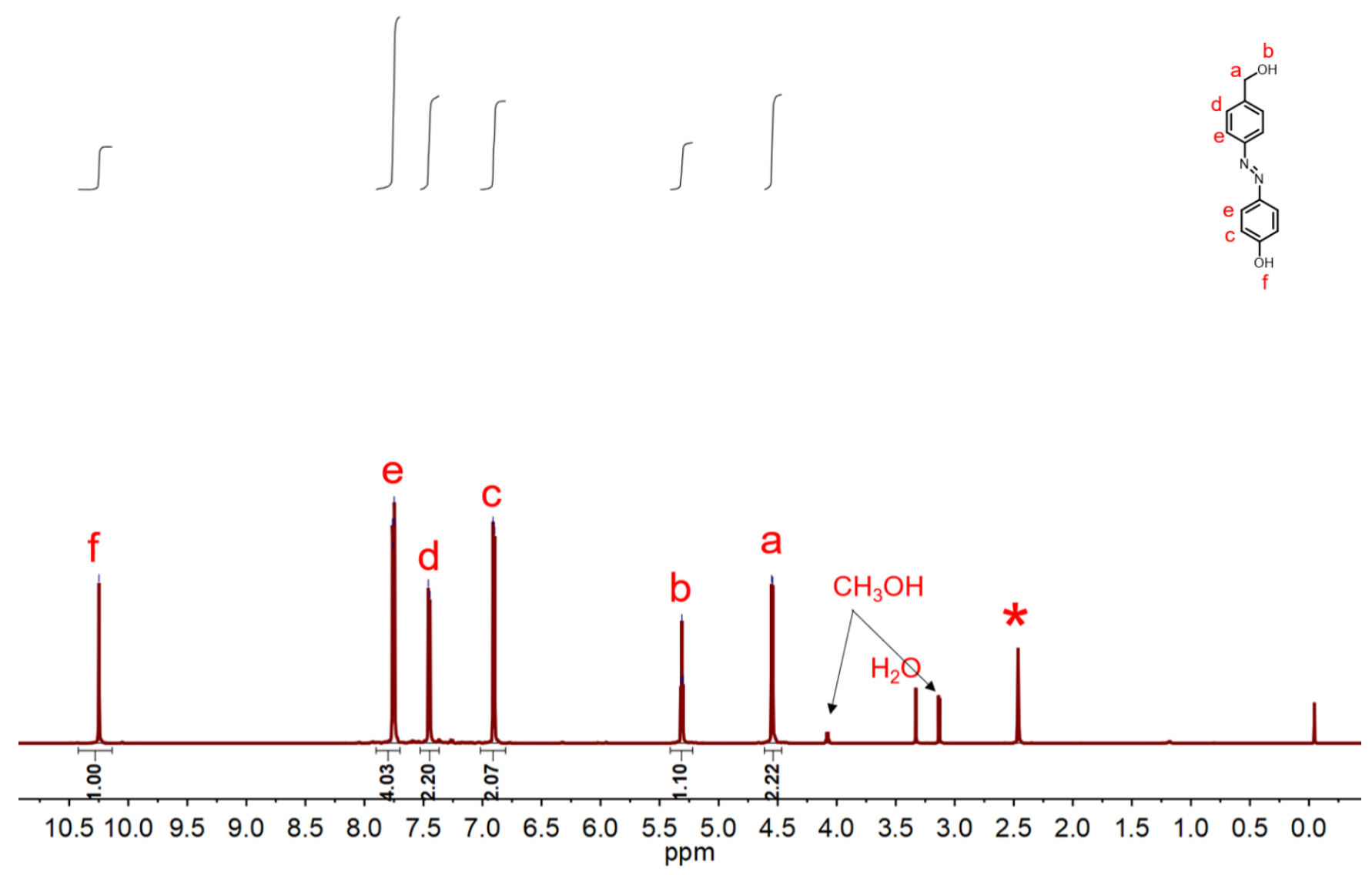

Figure S1(b). ${ }^{1} \mathrm{H}$ NMR spectra of AZO in DMSO-d6. The solvent peaks are marked with asterisks. 


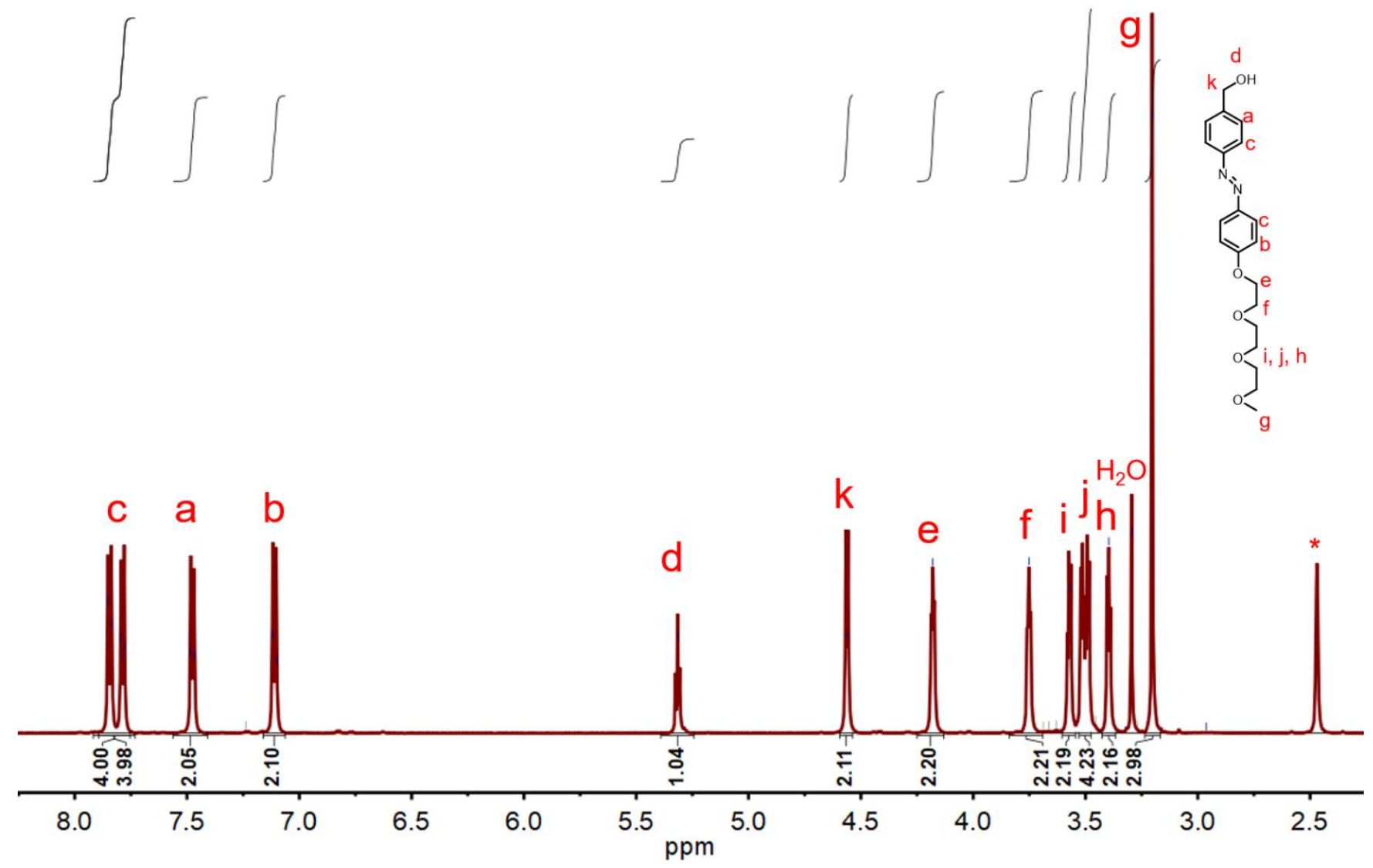

Figure $\mathbf{S 1}$ (c). ${ }^{1} \mathrm{H}$ NMR spectra of EAZO in DMSO- $\mathrm{d}_{6}$. The solvent peaks are marked with asterisks. 


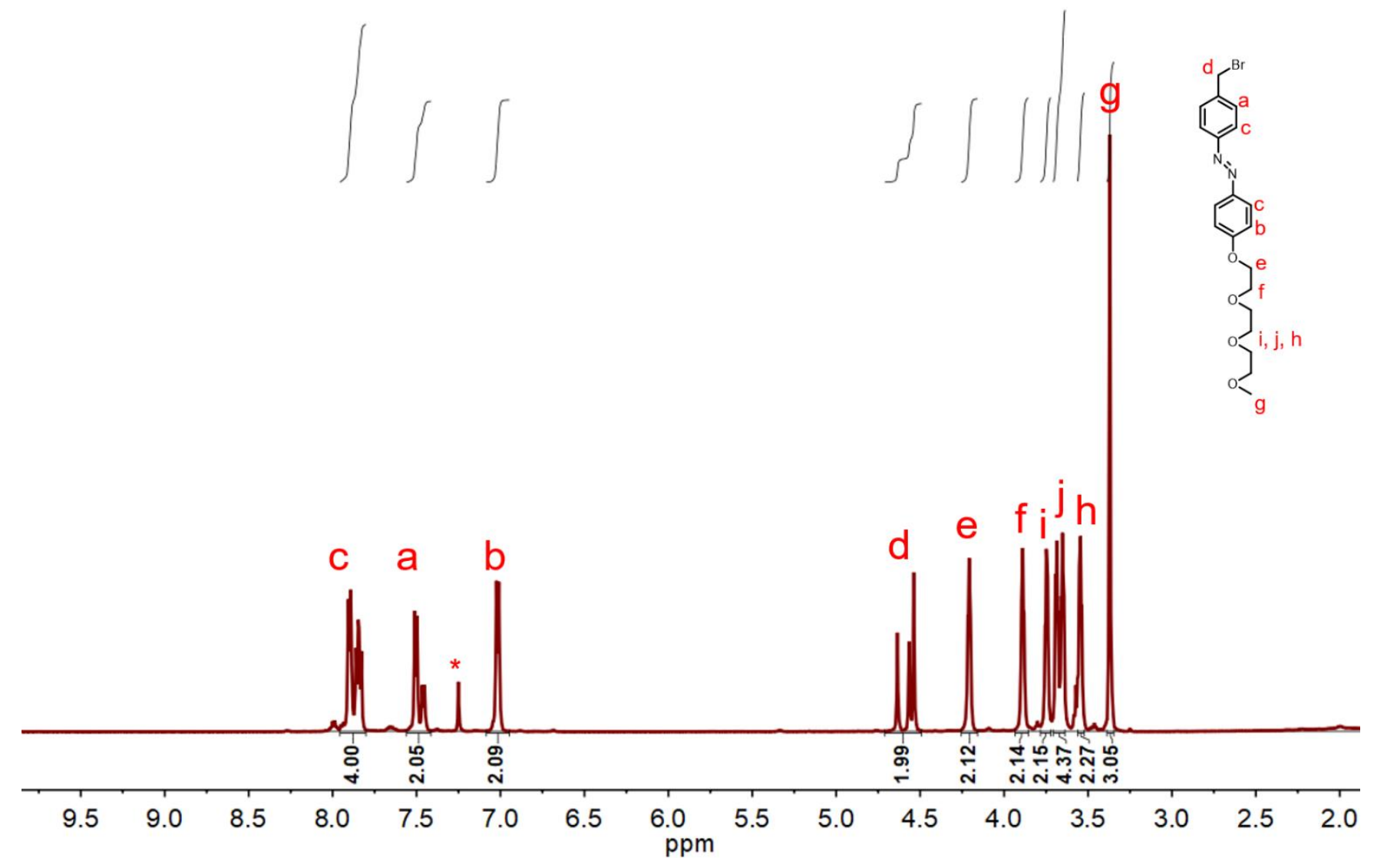

Figure S1(d). ${ }^{1} \mathrm{H}$ NMR spectra of $\mathrm{BEAZO}$ in $\mathrm{CDCl}_{3}$. The solvent peaks are marked with asterisks. 


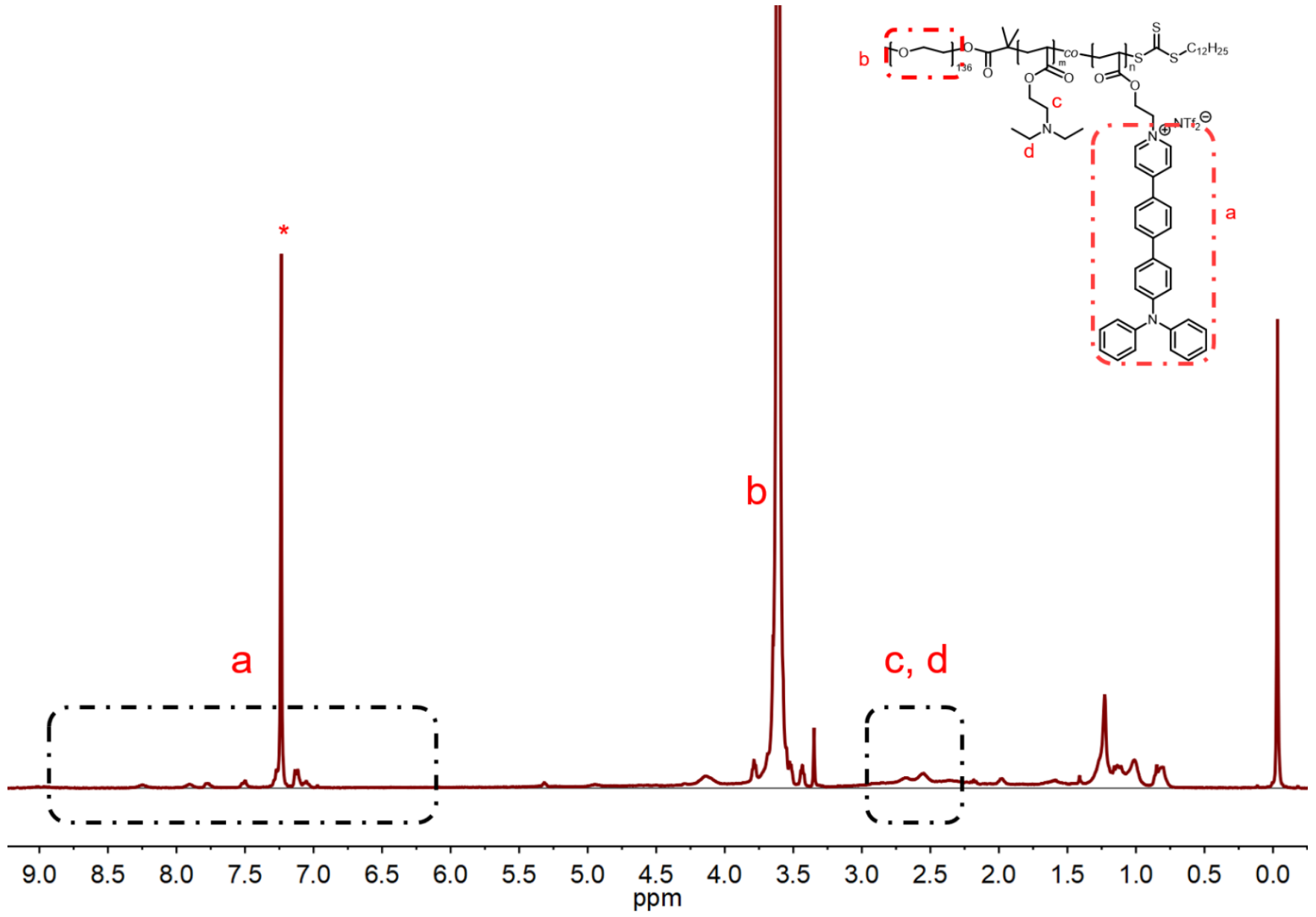

Figure S1(e). ${ }^{1} \mathrm{H}$ NMR spectra of PEG- $b-\mathrm{P}(\mathrm{DEAEA}-\mathrm{co}-\mathrm{TPMA})$ in $\mathrm{CDCl}_{3}$. The solvent peaks are marked with asterisks. 


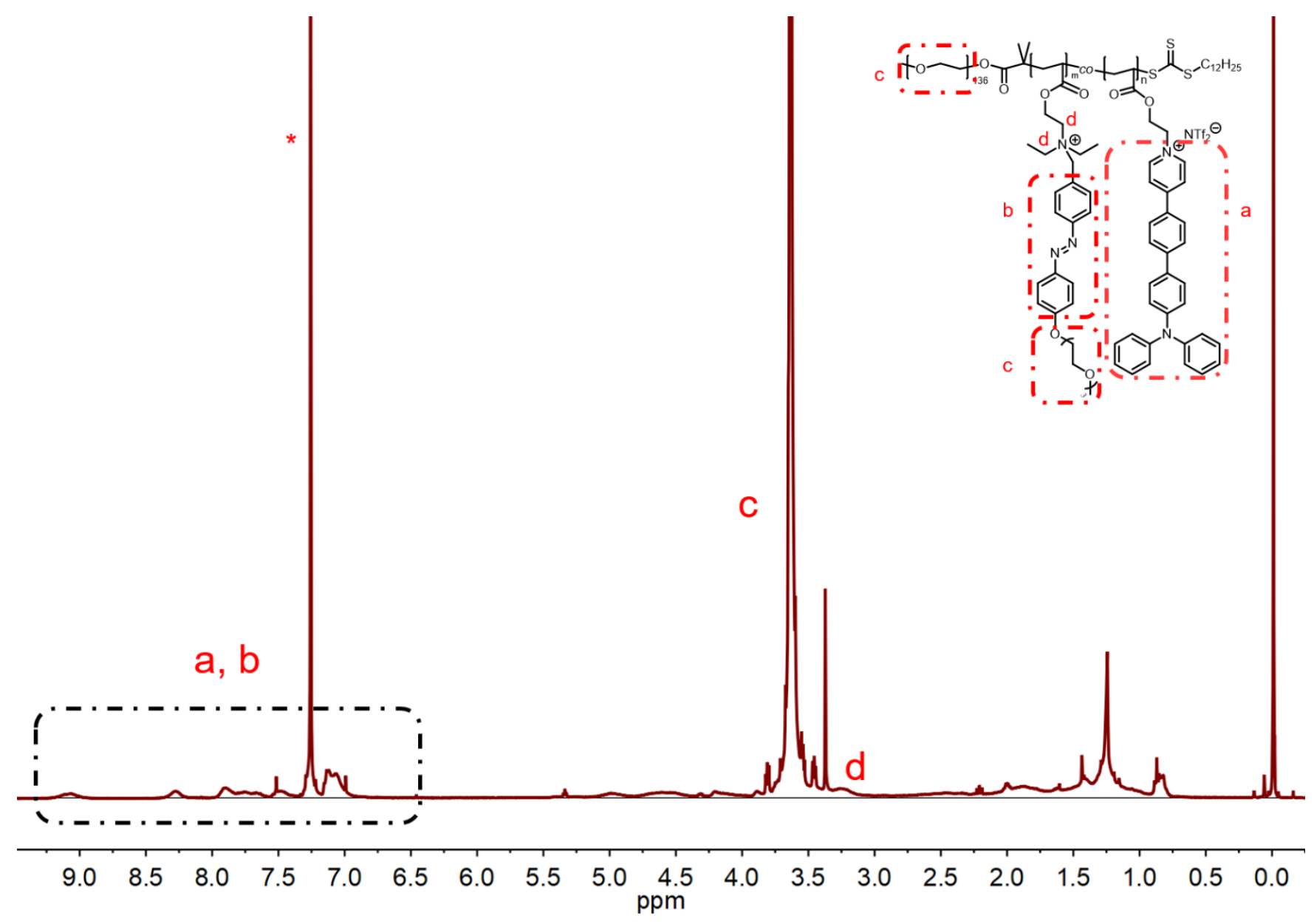

Figure S1(f). ${ }^{1} \mathrm{H}$ NMR spectra of PEG- $b$-P(DEAEAN-co-TPMA) in $\mathrm{CDCl}_{3}$. The solvent peaks are marked with asterisks. 


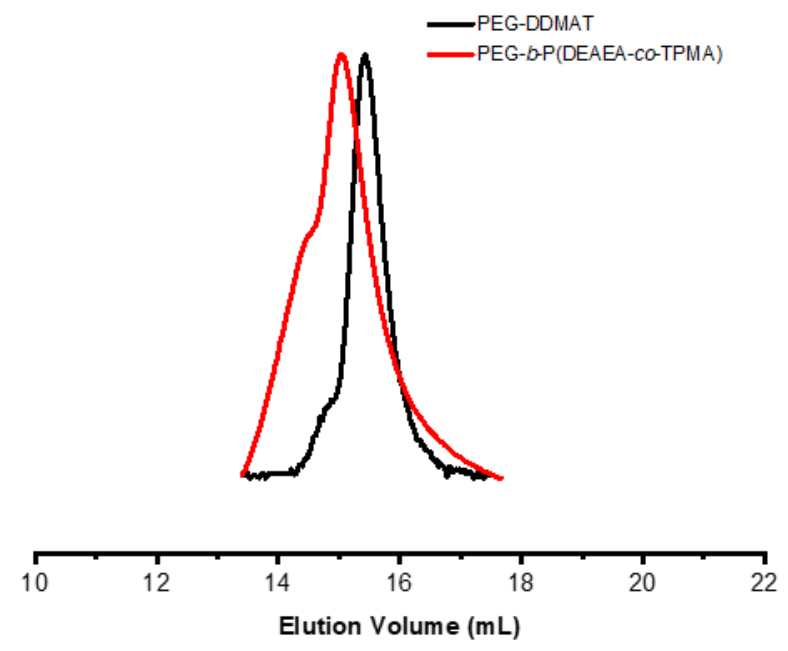

Figure S2. GPC test of PEG-DDMAT and PEG-b-P(DEAEA-co-TPMA).

PEG-DDMAT: $M n=7300, M w=7900, P D I=1.08$

PEG- $b-P(D E A E A-c o-T P M A): M n=15000, M w=17000, P D I=1.13$ 


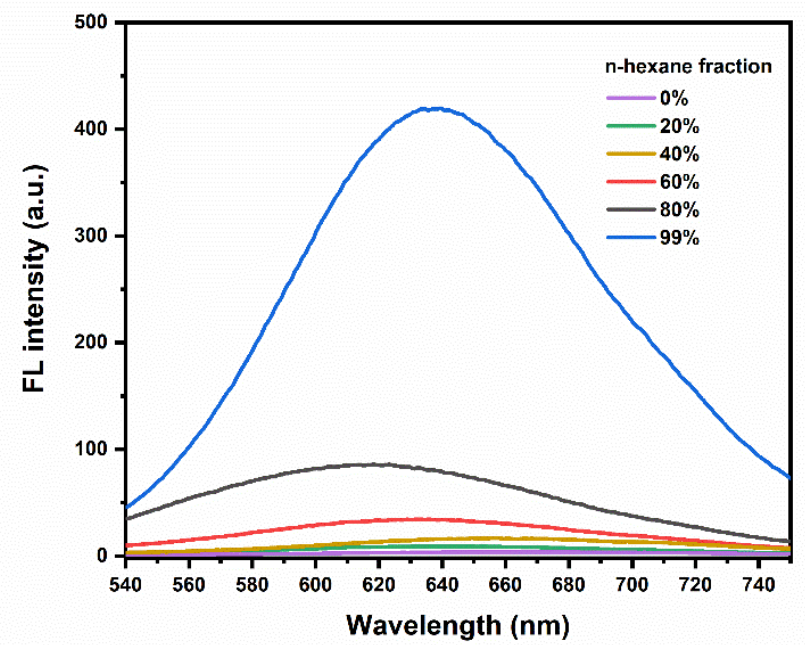

Figure S3. FL spectra of PEG- $b-\mathrm{P}(\mathrm{DEAEA}-\mathrm{co}-\mathrm{TPMA})$ in different ratios of THF and $\mathrm{n}$-hexane. $\lambda_{\mathrm{ex}}=405 \mathrm{~nm}$. 


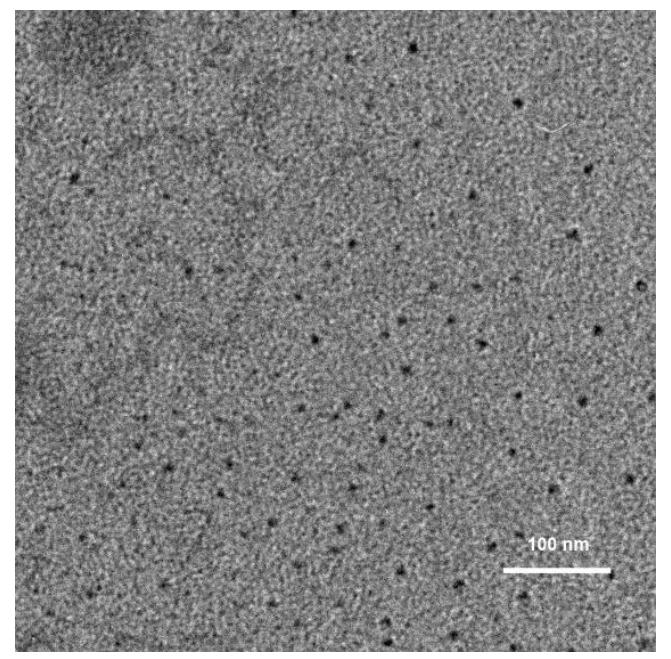

Figure S4. TEM image of PEG- $b$-P(DEAEAN-co-TPMA) before enzymatic reduction reaction. Scale bars: $100 \mathrm{~nm}$. 

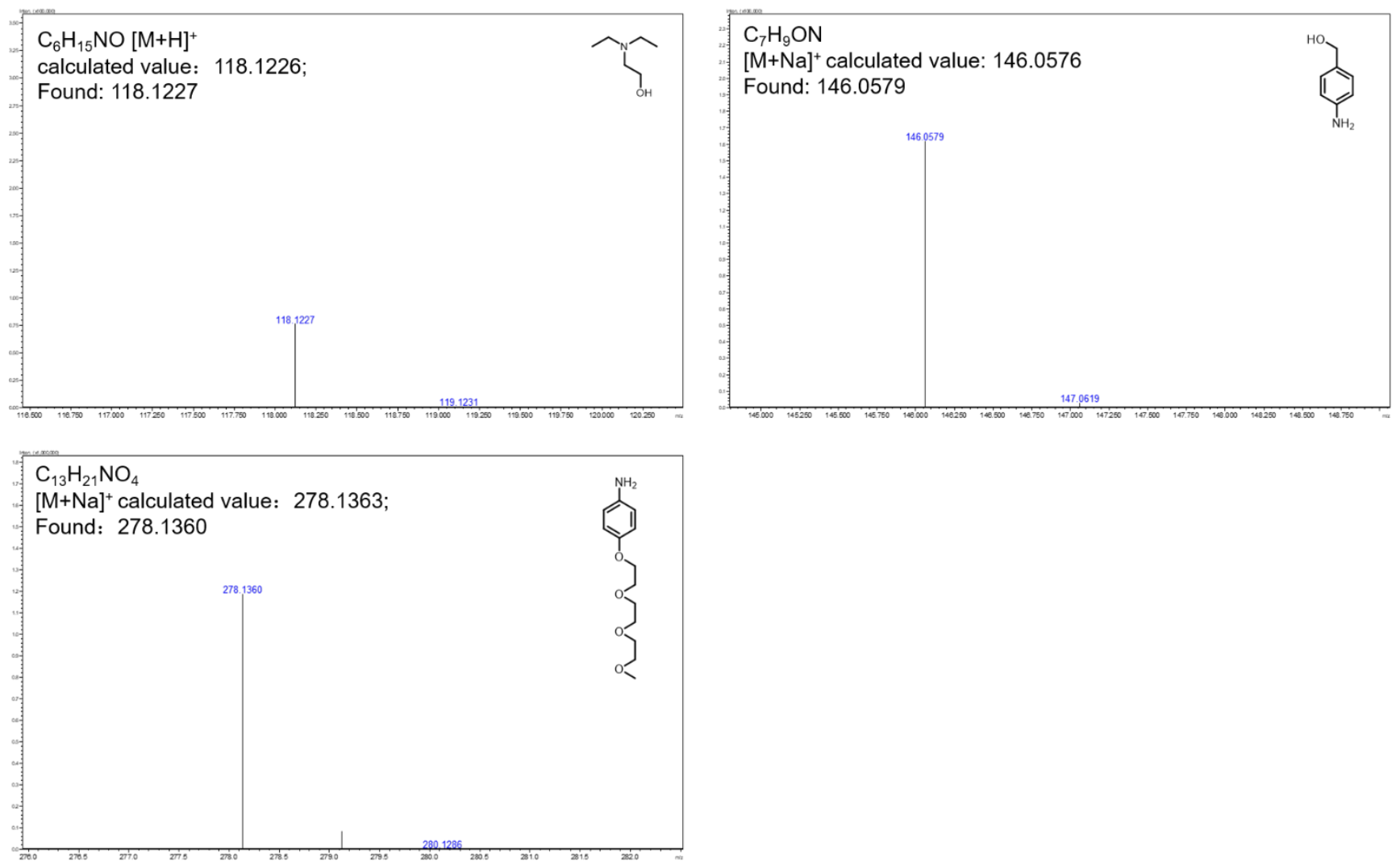

Figure S5. ESI-MS of components produced during enzymatic reduction reation and charge reverse process. 


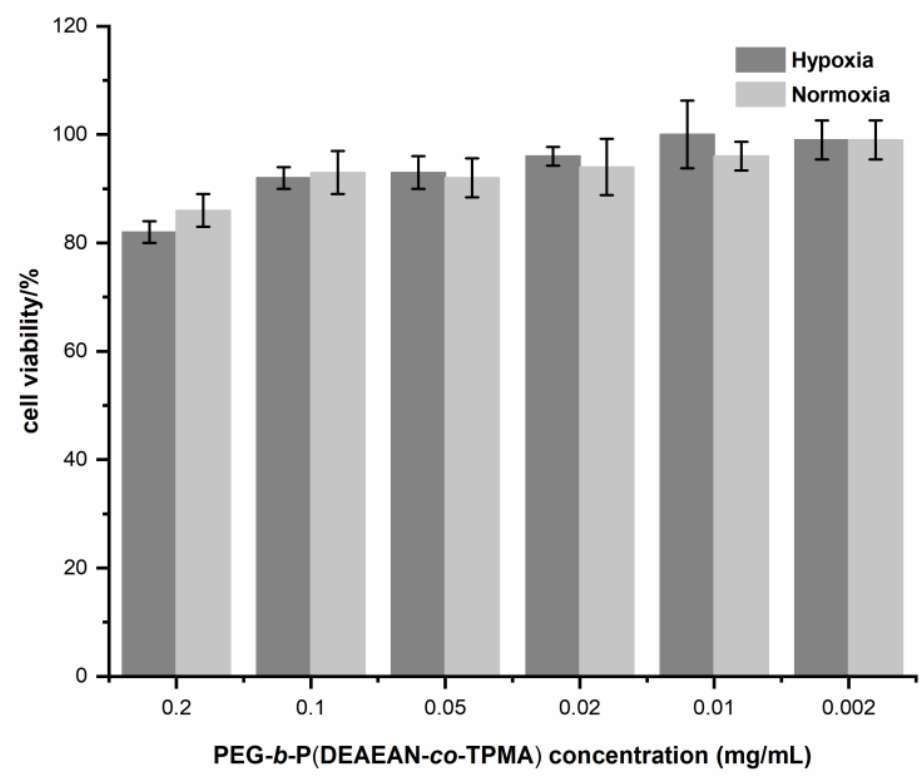

Figure S6. Cell viabilities of HeLa cells treated with different concentrations of PEG-b-(PDEAEAN-co-PTMA) under normoxic $\left(21 \%\right.$ v/v $\left.\mathrm{O}_{2}\right)$ and hypoxic (1\% v/v $\left.\mathrm{O}_{2}\right)$ conditions. 


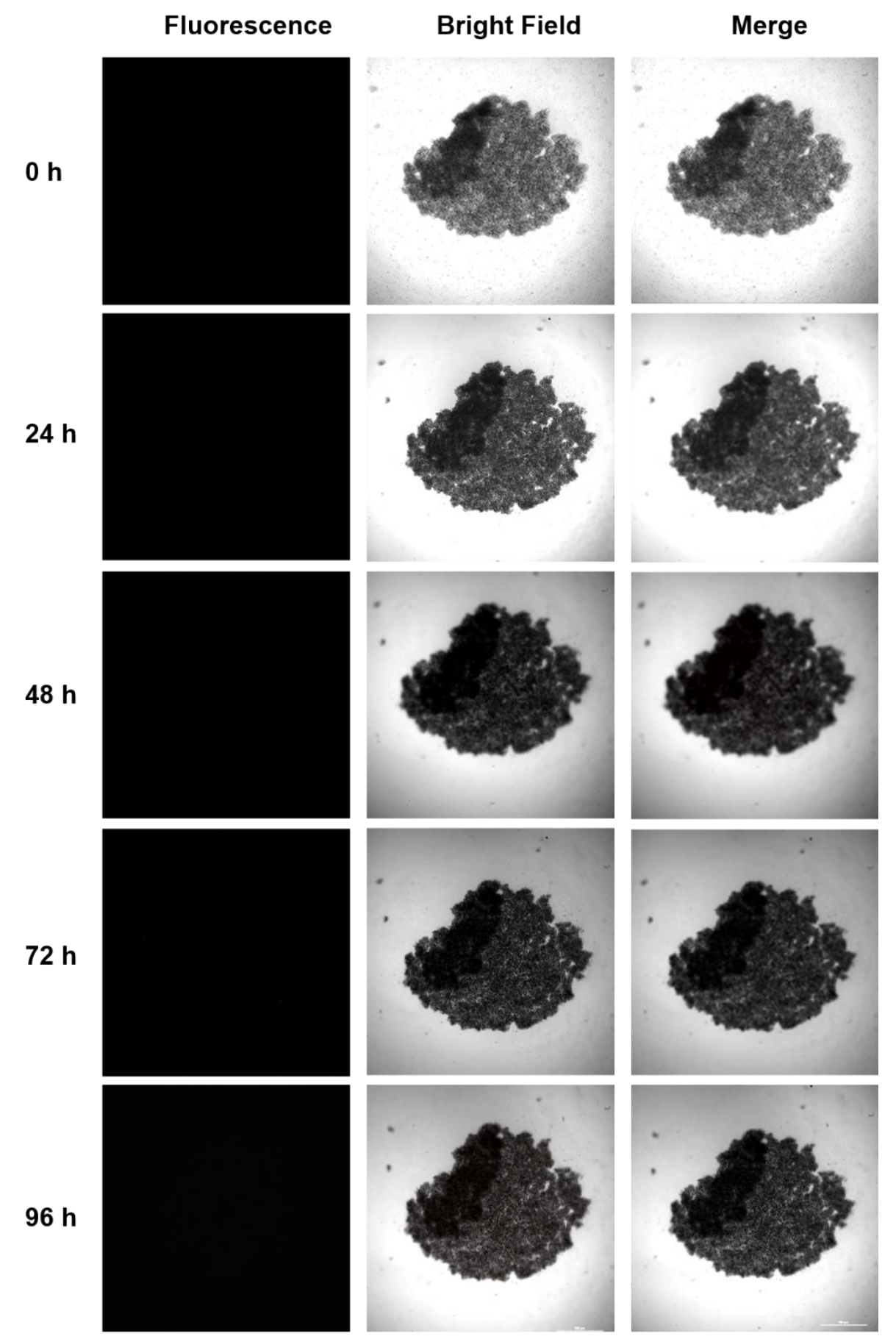

Figure S7. Confocal images of 3D MCTS incubated with PBS. $\lambda_{e x}=405 \mathrm{~nm}, \lambda_{\mathrm{em}}=550-590 \mathrm{~nm}$. Scale bars: $500 \mu \mathrm{m}$. 


\section{References}

(1) Zhuang, W.; Yang, L.; Ma, B.; Kong, Q.; Li, G.; Wang, Y.; Tang, B. Z., Multifunctional Two-Photon AIE Luminogens for Highly Mitochondria-Specific Bioimaging and Efficient Photodynamic Therapy. ACS Appl. Mater. Interfaces 2019, 11, 20715-20724.

(2) Hu, J.; Zhuang, W.; Ma, B.; Su, X.; Yang, L.; Li, G.; Wang, Y., A two-photon fluorophore labeled multi-functional drug carrier for targeting cancer therapy, inflammation restraint and AIE active bioimaging. J. Mater. Chem. B 2019, 7, 3894-3908.

(3) Ma, B.; Zhuang, W.; Xu, H.; Li, G.; Wang, Y., Hierarchical Responsive Nanoplatform with Two-Photon Aggregation-Induced Emission Imaging for Efficient Cancer Theranostics. ACS Appl. Mater. Interfaces 2019, 11, 47259-47269.

(4) Yu, T.; Zhuang, W.; Su, X.; Ma, B.; Hu, J.; He, H.; Li, G.; Wang, Y., Dual-Responsive Micelles with Aggregation-Induced Emission Feature and Two-Photon Aborsption for Accurate Drug Delivery and Bioimaging. Bioconjugate Chem. 2019, 30, 2075-2087.

(5) Fischbach, C.; Chen, R.; Matsumoto, T.; Schmelzle, T.; Brugge, J. S.; Polverini, P. J.; Mooney, D. J., Engineering tumors with 3D scaffolds. Nat. Methods 2007, 4, 855-860. 